\title{
Ultra-widefield versus conventional angiography in a postvitrectomy, partially gas-filled eye
}

\author{
Daraius Shroff, Shishir Narain, Charu Gupta, Cyrus Shroff
}

Shroff Eye Centre, New Delhi, Delhi, India

\section{Correspondence to Dr Daraius Shroff,} daraiuss@gmail.com

Accepted 13 February 2016

\section{DESCRIPTION}

We present a case where need for intervention in the fellow eye led us to a chance discovery in a postvitrectomy, gas-filled eye. Although theoretically aware of the ability of wide field imaging through gas, we captured the images presented by sheer serendipity.

A 38-year-old-man with OU proliferative diabetic retinopathy (PDR) and vitreous haemorrhage in OD underwent vitrectomy with perfluoropropane gas injection. Imaging was planned after absorption of the gas. However, 3 weeks postoperatively, he reported of seeing a floater in the unoperated eye. To perform immediate angiography-guided laser, we performed fundus fluorescein angiography (FFA) with Topcon TRC-50DX (Topcon, Tokyo, Japan) as well as on Optos (Dunfermline, Scotland).

Conventional angiography captured blurred images through the gas bubble. Figure 1 shows a montage to highlight the contrast between the images through the gas-filled and fluid-filled areas. On the other hand, the UWF FFA with gave a highly focused image revealing detailed angiographic information about the vasculature and capillary non-perfusion areas (figure 2).

The marked contrast in the two images would be because of differences in the principles of illumination and image capturing between the two modalities. ${ }^{1}$ To circumvent limitations inherent in a

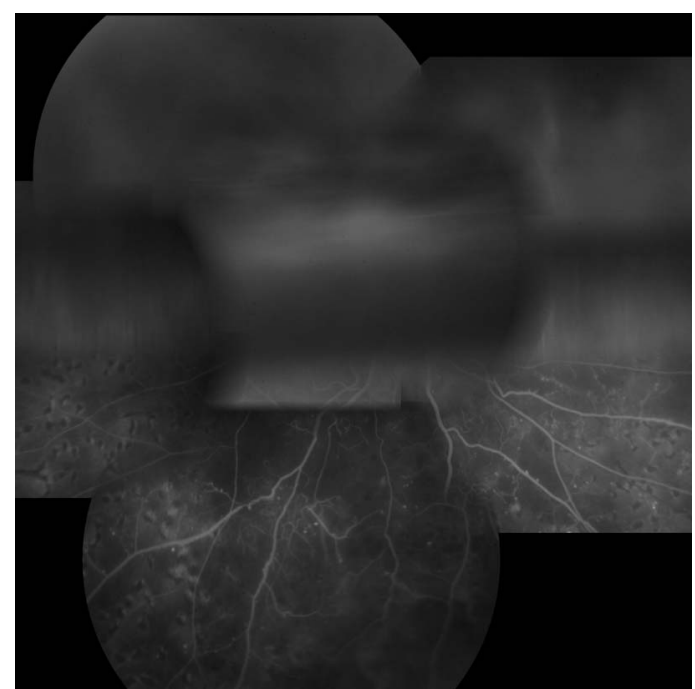

Figure 1 Conventional fluorescein angiography montage of the gas-filled eye. Inferiorly, below the gas bubble level, the retinal vasculature is imaged clearly. However, the image through the gas bubble in the upper half of the photograph is unfocused and hazy. No details at all can be appreciated.

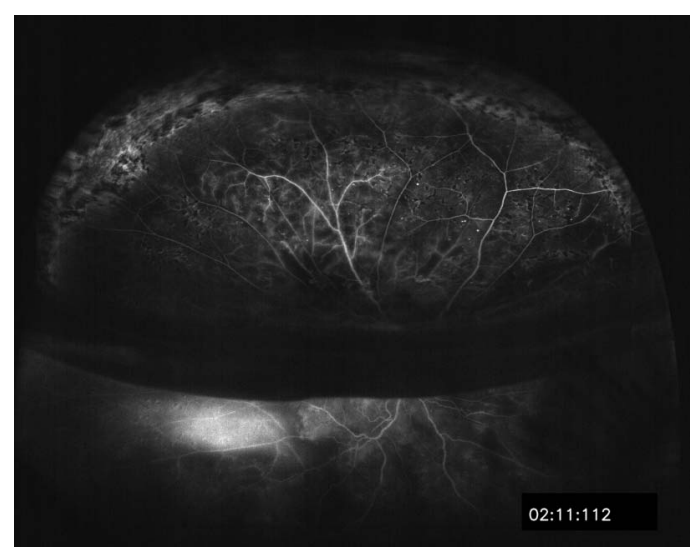

Figure 2 Ultra-widefield angiography with the Optos. The gas level meniscus is clearly seen bisecting the photograph. The retinal vasculature and laser marks along with areas of capillary non-perfusion are both seen clearly through the gas bubble superiorly.

conventional lens-based system with coaxial illumination, the ultra-widefield imaging system is based on an ellipsoidal mirror with two conjugate focus points. ${ }^{2}$ It uses a narrow scanning laser light source, ${ }^{3}$ which is the likely reason for minimal reflection and the excellent image obtained through the gas bubble in our case.

We present the first report, to our knowledge, comparing images captured by these two modalities in a partially gas-filled eye, postvitreous surgery.

\section{Learning points}

- Ultra-widefield angiography is able to capture a crystal clear image through a gas bubble in contrast with conventional angiography.

- Ultra-widefield imaging in postoperative cases with gas in situ would be a useful tool in cases where early imaging could influence patient management and outcome.

Contributors DS was involved in the substantial contribution to the conception of the work; drafted the work; involved in the approval of the version published; agrees to be accountable for all aspects of the work. SN was involved in the substantial contribution to the acquisition of data and design of the work; revised it critically for important intellectual content; involved in the final approval of the version published; agrees to be accountable for all aspects of the work. CG was involved in the substantial contribution to the conception and design of the work; revised it critically for important intellectual content; involved in the final approval of the version published; agrees to be accountable for all 
aspects of the work. CS was involved in the substantial contribution to the conception; revised it critically for important intellectual content; involved in the final approval of the version published; agrees to be accountable for all aspects of the work.

Competing interests None declared.

Patient consent Obtained.

Provenance and peer review Not commissioned; externally peer reviewed.

\section{REFERENCES}

1 Spaide RF. Peripheral areas of nonperfusion in treated central retinal vein occlusion as imaged by wide-field fluorescein angiography. Retina 2011;31:829-37.

2 Anderson DC, Lucas RA, Henderson R. Wide field scanning laser ophthalmoscope. US patent 5815242, 29 September 1998.

3 Nicholson BP, Nigam D, Miller D, et al. Comparison of wide-field fluorescein angiography and 9-field montage angiography in uveitis. Am J Ophthalmol 2014;157:673-7.

Copyright 2016 BMJ Publishing Group. All rights reserved. For permission to reuse any of this content visit http://group.bmj.com/group/rights-licensing/permissions.

BMJ Case Report Fellows may re-use this article for personal use and teaching without any further permission.

Become a Fellow of BMJ Case Reports today and you can:

- Submit as many cases as you like

- Enjoy fast sympathetic peer review and rapid publication of accepted articles

- Access all the published articles

- Re-use any of the published material for personal use and teaching without further permission

For information on Institutional Fellowships contact consortiasales@bmjgroup.com

Visit casereports.bmj.com for more articles like this and to become a Fellow 